Article

\title{
Inclusivity and Responsible Tourism: Designing a Trademark for a National Park Area
}

\author{
Edgardo Sica $^{1} \mathbb{D}$, Roberta Sisto ${ }^{1, * \mathbb{D}}$, Piervito Bianchi $^{2}\left(\mathbb{D}\right.$ and Giulio Cappelletti ${ }^{1}$ (D) \\ 1 Department of Economics, Management and Territory, University of Foggia, 71121 Foggia, Italy; \\ edgardo.sica@unifg.it (E.S.); giulio.cappelletti@unifg.it (G.C.) \\ 2 Department of Economics, University of Foggia, 71121 Foggia, Italy; piervito.bianchi@unifg.it \\ * Correspondence: roberta.sisto@unifg.it
}

check for

updates

Citation: Sica, E.; Sisto, R.; Bianchi, P.; Cappelletti, G. Inclusivity and Responsible Tourism: Designing a Trademark for a National Park Area. Sustainability 2021, 13, 13. https:/ / dx. doi.org/10.3390/su13010013

Received: 1 December 2020

Accepted: 18 December 2020

Published: 22 December 2020

Publisher's Note: MDPI stays neutral with regard to jurisdictional claims in published maps and institutional affiliations.

Copyright: () 2020 by the authors. Licensee MDPI, Basel, Switzerland. This article is an open access article distributed under the terms and conditions of the Creative Commons Attribution (CC BY) license (https: / / creativecommons.org/ licenses/by/4.0/).

\begin{abstract}
Responsible tourism provides a particular lens by which to consider how to improve the sustainability of tourism with the ambition to enhance the positive impacts of mainstream tourism, while reducing the negative ones. In this view, facilitating travel for people with disabilities represents an exceptional opportunity, and the idea that what is accessible to one traveler may be very difficult to access to another one with a different type of disability, makes inclusive tourism a relevant part of the global sustainable tourism agenda. The present study aims to provide empirical evidence on the adoption of the principles of responsible and inclusive tourism within a national park area. To this end, the paper discusses the case of the "E-Parks" research project which investigated the area of the Gargano National Park (Italy) with a special focus on the problems faced by tourists with disabilities, and on the improvements to enable all tourists to have the full enjoyment of their tourism experience. The study contributes, therefore, to enriching the empirical literature on inclusive and responsible tourism that has its application in the design of trademark procedural guidelines enabling tourists with different disabilities to access a protected natural area.
\end{abstract}

Keywords: sustainable tourism; inclusive tourism; responsible tourism; national park area; Gargano National Park; trademark specification for accessibility; tourists with disabilities

\section{Introduction}

Tourist activities have spread geographically to reach practically all countries of the globe, and their role in supporting income generation, foreign exchange earnings and employment creation is largely recognized in the literature, for both developed and developing countries [1-6].

However, with the increase of tourism, a series of negative impacts have begun to arise both at the national and international level. Descriptions of the ambivalent role that tourism plays in sustaining fragile environments, communities and cultures are well discussed in the tourism literature [7-11].

Awareness about sustainability issues has also developed significantly over the past 30 years. Currently, most governments, international institutions, universities and research centers, as well as non-governmental organizations, recognize that sustainability represents a precondition for a development, generating benefits to all stakeholders, solving problems such as extreme poverty, and preserving the precious natural and man-made resources on which human prosperity is based [12].

Concern for the environment and the understanding that mass tourism could have significant negative environmental impacts if it were not controlled, has led to great attention toward responsible and sustainable tourism [13-15].

Responsible tourism focuses on the choices made by visitors and their hosts, emphasizing changing behavior in order to change tourism outcomes. Thus, it provides a particular lens by which to consider how to improve the sustainability of tourism [11]. Its ambition is to enhance the positive impacts of mainstream tourism, while reducing the 
negative ones [16]. In this view, responsible tourism has caught the interest of researchers as well as tourism practitioners and tourists.

Moving along the accountable and ethical behavior perspective, a form of responsible tourism is represented by accessible tourism that should allow everyone to travel in conditions of autonomy, safety, and comfort [17-19]. However, starting from the existence of many kinds of disabilities, a more appropriate and complete objective for the tourism industry should be represented by "inclusive tourism". It is worth noting that, despite the relevance of these issues, conceptual considerations of responsible and inclusive tourism have received, so far, a very limited empirical reflection and, if not duly operationalized, they risk remaining empty concepts.

In this perspective, the study aims to provide empirical evidence of the adoption of the principles of responsible and inclusive tourism within a national park area, through the drawing of an operative tool improving the inclusiveness of a tourism destination.

To this end, the paper discusses the case of the "E-Parks" research project which investigated the area of the Gargano National Park (Italy) with a special focus on the problems faced by tourists with disabilities, and on the improvements to enable all tourists the full enjoyment of their tourism experience. By means of the qualified contribution of stakeholders, the research project has aimed to develop procedural guidelines to award a new trademark specification for public and private subjects operating in protected natural areas, combining the protection of the natural environment, the rational use of scarce resources, and the safeguard of tourists with special needs.

In regards, and to the best of our knowledge, there are no previous academic studies about the involvement of tourism stakeholders and the disabled representatives in designing a trademark specification from an inclusive and responsible tourism perspective.

The paper is structured as follows. Section 2 depicts the state of art concerning sustainability in tourism with a particular focus on responsible, inclusive and accessible tourism in natural areas. Section 3 investigates the case study and the adopted methodology, while the results are presented in Section 4. Section 5 ends the paper with the discussion and some concluding remarks.

\section{Sustainability in Tourism: A Theoretical Framework}

\subsection{Sustainable and Responsible Tourism}

The definition of sustainable tourism given by UNEP and UNWTO [12] as, “Tourism that takes full account of its current and future economic, social and environmental impacts, addressing the needs of visitors, the industry, the environment and host communities", is fascinating but still intrinsically lacking in meaningful content. Thus, as argued by some authors $[20,21]$, sustainable tourism risks to remain a beautiful but empty concept.

Moving along, the accountable and ethical behavior required when the negative implications of tourism's growth begins to trigger serious concerns, a new way of 'doing' sustainable tourism takes hold, such as responsible tourism [22,23] because it is by responsibly acting that sustainability can be achieved [14,24].

In short, responsible tourism is defined as "making better places for people to live in and better places for people to visit, requiring that operators, hoteliers, governments, local people, and tourists take responsibility and action to make tourism more sustainable" [25], (p. 1). It concerns the willingness to assume responsibility for making tourism more sustainable, from either the side of production or the consumption [16] with a closer look at the issues of intragenerational equity and the active involvement of stakeholders, sometimes muted in accounts of sustainable tourism [26]. The importance of involving multiple stakeholders in the production and management of action of responsible tourism was established in the 2002 Cape Town Declaration. This document emphasizes that sustainability in tourism is the objective that can only be achieved if various tourism stakeholders (governments, communities, businesses, and consumers) act with "responsibility" (that is, the means) $[27,28]$. In the same document, responsible tourism was defined as a three-tiered approach including: building a better place for local community; enhancing 
the tourists' experiences in destinations, and finally, creating better business opportunities for tourism enterprises $[29,30]$.

For some scholars, responsible tourism represents rather a multi-dimensional paradigm, a way of conducting business in a nature-based, cultural and community-based way [31,32], since the notion of responsibility relates to responsible behavior and action [33], which includes environmental protection, economic development, social equity and ecological effects, and relies on strong ethical values [32,34].

Responsible tourism is often treated synonymously with sustainable tourism, ethical tourism, and ecotourism [35]. Conversely, some authors [15] argue that, notwithstanding, responsible, ecotourism and sustainable tourism have a common objective of minimizing negative social, economic and environmental impacts, whilst maximizing the positive effects of tourism development, therefore, they should not be used interchangeably. This is not to say that the idea of responsible tourism, like sustainable tourism, is without its critics, with some seeing it merely as a self-justification for the continued growth of tourism markets [36]. Notwithstanding such critiques, the expression "responsible tourism" represents a sort of umbrella term including a wide range of social responsibility practices by industry actors and tourists themselves which is, by now, fairly well established [37].

Facilitating responsible behavior creates many questions such as who the relevant actors are, and who should make the relevant choices. Actually, all of them are relevant because each adds his own piece of knowledge, expectations and needs from a different perspective, requiring that fragmented issues be placed within a common framework $[33,38]$. In this view, the development of a strategy for responsible tourism among actors who are heterogeneous and pursuing different goals requires a complex process of participation and techniques able to disentangle this complexity, and that engages and empowers local communities in planning about the future development of their area [12,39].

\subsection{Inclusive and Accessible Tourism}

Literature lacks a universally recognized definition of inclusive accessible tourism, therefore, they are often used interchangeably.

Accessible tourism is also called "barrier-free tourism", and relates to enabling people with access requirements, including mobility, vision, hearing and cognitive dimensions of access, to function independently and with equity and dignity through the delivery of universally designed tourism products, services and environments [40-42]. This definition includes all people with temporarily disabilities, travelers with children in prams, and seniors. Indeed, accessible tourism is not just about providing facilities to wheelchaired disabled tourists because many travelers have different degrees of mobility restrictions or have invisible impairments that may not be immediately obvious just by looking at them.

In these abovementioned conditions, if we do not specify to which kind of disabled tourists, "accessibility" is addressed, this word risks remaining an empty concept without a specific meaning. Therefore, starting from the idea that what is "accessible" to one traveler may be very difficult to access to another one with a different type of disability, "inclusive tourism" seems to be a more appropriate, complete and ambitious objective for the tourism industry than focusing just on "accessible tourism".

Inclusive tourism intends to pursue equality among travelers, through the planning of a trip using facilities, services and activity programs guaranteeing the traveler with disabilities or special needs to take advantage of the cultural, experiential and emotional enrichment linked to the travel, like an able-bodied person taking into account the times and needs of the disabled traveler himself. This form of responsible tourism should allow everyone the opportunity to travel, to stay and take part in events without encountering any problem or difficulty, in conditions of autonomy, safety and comfort [17-19].

From a business competitiveness view, with the growing importance of the accessible tourism market, facilitating travel for people with disabilities represents an exceptional opportunity. Therefore, to remain competitive, inclusive tourism must be part of the global sustainable tourism agenda. Accessible environments and services contribute to increase 
the quality of the tourism offer and consequently, the overall competitiveness of tourism destinations. Accessibility, therefore, represents the precondition of any responsible and sustainable tourism policy and strategy [43].

In particular, this attention should also be paid to the families of those with disabilities by granting them with autonomy in traveling and using different services, reliability of information on facilities, and meeting those with disabilities' needs for the whole holiday. This is not only for cultural reasons, but also for medical aims. Indeed, some studies $[44,45]$ have highlighted the benefits that outdoor activities may provide to the population and, in particular, to people with different types of disabilities. From the abovementioned considerations, it is worth mentioning the relevant role played by protected natural areas, which represent tourism destinations that have been little practiced so far by people with disabilities due mainly to accessibility problems. The 2003 Norcia Declaration [46] sets out, in more detail, the way to ensure accessibility and usability of parks and other protected natural areas. In particular, it states that both people with special needs and their families should be fully involved in the decision-making process aimed to implement all the solutions to guarantee the full accessibility to protected natural areas. The involvement of disabled people in drawing up guidelines for outdoor tourism activities, along with the actors that already operate in the tourism sector, is definitely an innovative bottom-up approach since this provides tourists with disabilities and their families with the possibility to express the most suitable solutions to overcome their difficulties and meet their needs. Therefore, sustainable tourism can only be achieved through an inclusive and participatory approach in which all stakeholders, including persons with disabilities, are engaged to create solutions and opportunities for and with persons with disabilities [34]. However, the involvement of people with disabilities in tourism destinations still represents a challenge, as it is a topic which is seldom approached [45]. Indeed, an important aspect that resulted from different studies is the lack of marketing communication, and the facilities in tourism are suffering serious gaps in communication with people with disabilities. The communication process does not help these people to be included in tourism facilities, it does not help them to step-out the barriers and it does not support them to take the purchasing decision [45].

In this abovementioned perspective, the definition of trademark guidelines to award those tourism suppliers committed to the principles of responsible tourism may represent a useful tool to implement all those measures necessary to ensure the full enjoyment of natural parks. In particular, the definition of such guidelines should follow a shared and participatory approach from its drafting to its implementation in order to better understand and overcome all the obstacles that impede people with special needs to fully enjoy their tourism experience [47-49].

\section{Materials and Methods}

\subsection{The Context of Analysis}

This research represents the outcome of the E-Parks ("Environmental and Administrative Knowledge Networks for a Better Tourist Attractiveness in Protected Natural Areas") project, which has been carried out within the Interreg V-A Greece-Italy Programme 2014-2020, and involved universities, research organizations and institutions both from Italy (University of Foggia, Gargano National Park, Gargano Reclamation Consortium) and Greece (Chamber of Commerce of Arta, Technological Educational Institute of Western Greece).

The project aimed at improving accessibility and usability of protected natural areas and focused, in particular, on the case of the Gargano National Park, in the southeast of Italy. The Park-established in 1991-encompasses an area of approximately 120,000 hectares and includes 18 municipalities. The presence of many religious sites, historical attractions, and protected natural areas provides the Park with a strong tourism potential, as proven by the increasing number of yearly visitors, which moved from approximately 790,000 in 2014 to 850,000 in 2018 [50]. In this framework, the possibility of guaranteeing the full 
inclusiveness of tourists with special needs represents, hence, a worthwhile matter of investigation. To this end, a relevant outcome arisen from the project was the development of procedural guidelines to award a special trademark (namely, the "E-Parks Trademark") to those tourism suppliers which demonstrate to be particularly engaged in the improvement of tourism accessibility for different categories of disabled people. Although specifically addressed to public and private subjects (hotels, restaurants, museums, shops, etc.) operating in the Gargano National Park, the guidelines and the related trademark can be potentially adopted in other protected natural areas with the aim of enhancing their accessibility.

To be awarded with the trademark, tourism suppliers must demonstrate to follow the set of principles and predetermined criteria included in the guidelines. The applicationwhich occurs exclusively on a voluntary basis-starts with a self-assessment process followed by an external and recurring verification from inspectors. Being awarded with the trademark allows tourism suppliers to increase their awareness regarding disability, to access niche markets and to foster networking activities. As argued in Section 2.2, accessibility is a central element of responsible and sustainable development policies and may represent not only a human rights imperative but even an exceptional business opportunity. By contributing to the full accessibility of the Gargano National Park, hence, the trademark can provide a relevant benefit to many different actors, primarily to persons with disabilities and tourism suppliers.

\subsection{Methodology}

The guidelines definition can be a very tricky issue. Specifically, when they are too stringent or, conversely, when the trademark is not perceived as something really improving tourist accessibility, then tourism operators might not apply for being certified. As a consequence, the full involvement of different stakeholders is essential to gather their perspectives, needs and experiences, and include them in the guidelines' development process. To develop the trademark guidelines, we followed, therefore, a qualitative methodology which represents the optimal method to achieve the proposed objective. More specifically, the research process was carried out from January to October 2019 and consisted of four phases:

1. legal framework definition and literature review

2. focus group design

3. data collection

4. data analysis.

These phases are detailed below:

Phase 1: Legal framework definition and literature review. The starting point for the guidelines' definition was the in-depth study of the mandatory requirements set by the Italian laws on disability and was carried out from January to February 2019. Similarly, exhaustive desk research based on the official and grey literature (i.e., scientific publications, reports, journal articles, websites) was conducted to identify facilities and services that may contribute to improve the tourism experience of disabled peoples. Since the obstacles to accessibility encountered by people with disabilities may differ substantially according to the type of tourism suppliers, the latter have been organized into three groups, namely:

(i) hotels and restaurants

(ii) shops and public offices

(iii) cultural places (i.e., nature routes, archaeological and botanical areas, gardens, museums).

Thus, at the end of phase 1, the draft of three distinct guidelines was developed, containing the specific accessibility requirements that each group of tourism suppliers should meet in order to be awarded with the trademark.

Phase 2: Focus group design. The qualitative methodology adopted was based on the focus group which we consider the most suitable data collection technique for achieving our research objectives. In this phase, carried out in March 2019, we made a meticulous 
selection of participants in the focus group discussion, creating a broad representation of different stakeholders. Given their large heterogeneity, these were selected by ensuring a balance of power among them so that each could be represented by an equal voice at the table. Overall, we identified 298 stakeholders that we grouped into four categories, specifically:

(i) government or public sector (i.e., policymakers, state/regional/district and municipal level institutions)

(ii) civil society (i.e., non-profit organizations, such as disabled people's associations, university research institutes, local community organizations and other groups)

(iii) private sector (i.e., for profit such as firms, industry associations, etc.)

(iv) general public.

Phase 3: Data collection. The research data were collected through two semi-structured, interrelated, and consecutive focus groups where members of the research team acted as facilitators and moderators of the discussion. The first was carried out in April 2019 and aimed at discussing with participants about the preliminary findings achieved from the legal framework definition and literature review. Overall, 42 out of 298 stakeholders actually took part in the event. After a plenary session aimed at introducing the research project and the participants, the focus group proceeded into three operational tables targeted at each group of tourism suppliers (hotels and restaurants, shops and public offices, cultural places). Stakeholders were left free to choose which table to join according to their main interests and expertise. In this way, they had the opportunity to discuss in detail the draft of the trademark procedural guidelines, amending the text when necessary and adding proposals and suggestions. Any change in the guidelines was shared among participants and approved by all of them. This allowed to detect the stakeholders' viewpoint concerning the improvement of Gargano National Park's accessibility and to identify the main actions to be included in the guidelines.

After new guidelines were drafted in May 2019 to incorporate suggestions, proposals, and comments arisen in the meeting, a second focus group was carried out in June 2019 with the aim of checking whether the stakeholders' viewpoint was fully included in the new document. Twenty-six stakeholders took part in the event, 11 of whom did not participate in the first focus group. Again, the new focus group was organized with a plenary session followed by three operational tables. However, in this case, stakeholders who participated in the first focus group were asked to join a different table to diversify their contribution. As with the first focus group, stakeholders at any table had the opportunity to share their opinions and viewpoints about the new draft of the trademark procedural guidelines, suggesting changes or integrations when necessary.

Phase 4: Data analysis. This phase took place in two different moments. The first can be traced back to May 2019 when the findings achieved from the first focus group were incorporated in the new guidelines' draft. The second, to July-October 2019, when the final version of procedural guidelines was finally developed. The latter was then sent to all stakeholders (including those who participated in one focus group only) to provide a robustness check and to validate results obtained.

\section{Results}

The in-depth study of EU and Italian laws on disability revealed the general lack of regulations to specifically discipline accessibility of disabled people to tourist destinations. Among the few exceptions, it is worth mentioning Law 104/1992 (as integrated by Law 17/1999), which explicitly establishes that the Government concessions for bathing facilities are subject to the effective possibility of access to the sea for disabled people, and Ministerial Decree 6 October 2003, which defines the technical regulations for fire prevention in tourism accommodation facilities. In contrast, most of the laws dealing with disability aim at guaranteeing, more generally, equal opportunities to persons with special needs and providing them with rights, integration, and social assistance. This is the case, among the most recent, of Law 4/2004 as updated by Legislative Decree 106/2018 on the 
access of disabled people to computing, Law 22/2006 ruling home voting for disabled, and Law $67 / 2006$ on the protection of disabled people who are victims of discrimination. Regarding other national laws of interest for designing the trademark guidelines, it is worth mentioning those aimed at eliminating architectural barriers to public and open-to-public buildings, such as Law 13/1989 ("Provisions to promote the elimination of architectural barriers in private buildings"), Ministerial Decree 236/1989 ("Technical prescriptions to guarantee accessibility of private buildings"), Presidential Decree 503/1996 ("Regulations for the elimination of architectural barriers in buildings, spaces and public services") and Legislative Decree 380/01 ("Consolidated text of laws and regulations on construction").

Moving from this legislative framework, the draft of procedural guidelines developed in phase 1 enriched the mandatory requirements set by law by adding a number of supplementary conditions concerning services and facilities for disabled people that tourism suppliers should meet in order to be awarded with the trademark. These involve transparency of information about accessibility, external and internal characteristics of tourism facilities, presence of accessible toilet services, safety systems for disabled people, etc.

The above conditions were thereafter discussed point by point with stakeholders who considered all of them absolutely necessary to guarantee the full accessibility to the Gargano National Park, and provided interesting insights for their further refinement. They also identified an additional set of mandatory requirements in order to award tourism suppliers with the trademark and suggested to organize guidelines, not only according to the kind of tourism supplier (i.e., hotels and restaurants, shops and public offices, cultural places) but also on the basis of their applicability to different kinds of disability. Each guideline was accordingly divided into three sub-sections in order to tailor requirements to (i) physical disability, (ii) mental, intellectual, and sensory impairment (blind, deaf), and (iii) allergies and special dietary needs. In this way, tourism suppliers may be awarded with a specific trademark according to the disability they are able to deal with. More specifically, the "E-Parks Trademark for Physical Disability" is provided to those tourism suppliers that meet all the requirements related to this kind of disability, while the "E-Parks Trademark for Mental Disability" and the "E-Parks Trademark for Food Disability" to those that respect all the mandatory conditions for guaranteeing the full accessibility to people with intellectual and food disabilities, respectively. Of course, a tourism supplier can apply for and obtain all three trademarks.

Guidelines - as validated by stakeholders - are listed below. For brevity reasons and considering aims and scope of the Journal, we report the main mandatory requirements included in the guidelines, grouped in thematic areas. The full version is available on request.

\section{The Guidelines}

1. Transparency of information about accessibility (for all kind of tourist suppliers). To be awarded with the E-Parks Trademark, tourism suppliers must ensure information transparency with regard to the services provided. In this perspective, they should spread information about accessibility through a dedicated website, using more than one social network (e.g., Facebook, Instagram) other than by means of traditional tools (e.g., printed brochures). The information must be published using an "easy to read language" and employing images/graphics to facilitate understanding by people with intellectual disabilities. In case of videos, subtitles and sign language should be added. Information on paper must also be produced in Braille language. Additionally, the website must also be functional for the blind/visually impaired, through the possibility of listening to audio files. Moreover, an online booking system accessible to disabled people must be created in order to acquire information useful for providing them with a personalized welcome.

2. External accessibility (for all kind of tourist suppliers). Wheelchair visitors must be able to easily access the facility. To this end, tourism suppliers should remove any obstacle in the external area so that the floor becomes uniform, not disconnected and with 
slopes not higher than $8 \%$. Moreover, a board/monitor should be placed outside the facility at maximum $140 \mathrm{~cm}$ from the ground to show accessibility information, such as opening days and hours, and contact details of the person in charge to welcome disabled people. Printed information should be translated in Braille language and also be available in audio format to help blind/visually impaired people.

3. Solutions to facilitate entry (for all kinds of tourist suppliers). The main entrance to the tourism facility must be at least $120 \mathrm{~cm}$ large (compared to $90 \mathrm{~cm}$ set by law) to allow easy access for wheelchair visitors. The force to be applied for opening entrance doors/gates should not be exceeding $3 \mathrm{~kg}$ (definitely less than $8 \mathrm{~kg}$ set by law) or, alternatively, automated solutions should be adopted. In the presence of a counter door, the distance from the main door must be at least 2 meters; otherwise, the counter door must be opened on the opposite side to the entrance door in order to avoid obstructing the passage. Moreover, tourism suppliers should make glass doors easily visible by using stickers or bands at a suitable height (maximum $140 \mathrm{~cm}$ from the ground).

4. Toilet services and safety systems (for all kinds of tourist suppliers). The door's width for internal and external toilet services should be not less than $90 \mathrm{~cm}$ and the force to be used for their opening must not exceed $3 \mathrm{~kg}$ (therefore, less than the level set by law). The flooring must allow the easy passage of wheelchairs, and the distance to toilet, shower space and washbasin must not be less than $90 \mathrm{~cm}$. The toilet height should be $45-50 \mathrm{~cm}$ and toilets must be equipped with a hand shower. Similarly, the washbasin height, if not adjustable, should be $80-85 \mathrm{~cm}$, and an easily reachable call bell should be placed next to the toilet and shower.

5. Internal accessibility (for all kinds of tourist suppliers). Internal paths and other transit routes must be no less than $150 \mathrm{~cm}$ large to facilitate stopping, reversing and the simultaneous passage of two wheelchairs. Any longitudinal slope (maximum 5\%) must be properly marked and a maximum transverse slope of only $1 \%$ is allowed. The flooring must have easy-to-walk surfaces to allow wheelchair visitors to move easily. When routes have slight level variations, the presence of elevators and ramps must be guaranteed.

6. Breakfast/restaurant/bar rooms (for hotels/restaurants only). Breakfast/restaurant/bar rooms must be easily accessible and equipped with all the necessary facilities (e.g., elevators, ramps, staircases, elevator platforms). Furniture should be not sharp and not likely to cause personal injury. The presence of an adequate number of tables for disabled visitors should be assured with a maximum of 70-cm tabletops.

7. Internet services (for hotels only). Hotels must supply a Wi-Fi connection and a dedicated internet station to people with reduced mobility. The support surface must have free space underneath of at least $90 \mathrm{~cm}$ from the ground and a free surrounding space of at least $100 \mathrm{~cm}$.

8. Checkout desks and dressing rooms (for shops only). Checkout desks in shops must be maximum $90 \mathrm{~cm}$ from the ground and positioned in an area suitable for wheelchair use. Price tags should be positioned at a suitable height and must be easily readable. To this end, an adequate font size must be employed (not less than 16 point) and information in Braille language included, too. At least one dressing room should have dimensions suitable for access (not less than $90 \mathrm{~cm}$ ) and for internal movement of disabled people (not less than $140 \times 90 \mathrm{~cm}$ ), and must be equipped with shelves placed at no less than $140 \mathrm{~cm}$ from the ground.

9. Benches and rest areas (for cultural places only). Benches must be in proportion to the reception capacity of the tourism facility and at least $20 \%$ of them must be for the exclusive use of the disabled. Their size should be approximately $45 \mathrm{~cm}$ (height), 40-50 cm (depth), and $50 \mathrm{~cm}$ (width). In case of playgrounds, part of them should be accessible to children with disabilities. Similarly, at least $10 \%$ of rest areas must be dedicated to disabled persons. Tables in dedicated rest areas must have rounded 
edges and should be conceived in order to be approached on both the short and the long side rather than positioned on a completely flat area.

10. Quality assessment (for all kinds of tourist suppliers). Tourism suppliers should provide disabled people with assessment forms for evaluating the accessibility services offered. Forms must be adapted to the needs of the disabled person and can be filled traditionally (on paper) or digitally (via internet/apps).

11. Duly trained staff (for all kinds of tourist suppliers). In any tourism facility, at least one staff member should be trained on the topic of disability in order to welcome disabled visitors and provide them with all the necessary information about accessibility and assistance.

\section{Discussion and Concluding Remarks}

The analysis of the literature on responsible tourism as well as of contributions on inclusive, sustainable tourism, etc., and the study of policy papers, has revealed that in the near future, with increased awareness and appreciation of the positive benefits, responsible tourism will gain ground with a larger market segment. This depends not only on the growing tourist demand but on governments and tourism industries that are moving in that direction.

Indeed, in times of intense tourism development and environmental-social problems which are the consequence of this development, the implementation of the principles of sustainable and responsible tourism is the only safe way for the tourist industry to grow.

The aim of this study was to provide empirical evidence about the adoption of the principles of responsible and inclusive tourism within a national park area, through the drawing of an operative tool improving the inclusiveness of a tourism destination. In this framework, we have focused the analysis on the case of the Gargano National Park which, if fully inclusive for tourists with particular access requirements, may represent a valuable case of responsible tourism. Specifically, the social/ethical sustainability would be added to the economic and environmental ones, contributing to the overall development of the area.

National parks seem to be the entities which could, to a great extent, participate in social education promoting sustainable tourism. It is justified for many reasons. A national park, as a form of nature protection, may be publicly available only in the sustainable variant, hence, as an institution, it is predisposed to promote the principles and culture of sustainable and responsible tourism. What is more, the task of national parks is also to make their resources available for, among others, the needs of tourism, and to educate. Therefore, education promoting sustainable, responsible and inclusive tourism fits the scope of the parks' activity.

Such a multi-layered educational activity carried out by national parks could help to raise the social awareness and the level of culture in tourism, in line with the idea of sustainable development [51].

Park managements and tourism associations are increasingly aware of the fact that tourism which aims at outstanding natural heritage sites is able to change the view and understanding of the local population concerning the benefits of conserving the environment. Thus, it is crucial to involve all relevant stakeholders from the beginning as well as continuously into the decision-making processes, and define boundaries of tourism and nature conservation clearly.

The main finding of this study was drawing the guidelines to award tourism suppliers with a trademark for increasing the inclusiveness within a national park area. It represents an operative tool in order to achieve the responsible tourism goals. Indeed, as highlighted in the literature, sustainable tourism as well as responsible and accessible tourism, risk to remain empty concepts, if not duly operationalized. It is worth noting that requirements defined in the guidelines are more stringent than those established in national and regional regulations on disability. Therefore, being awarded with the E-Park Trademark means to be actively committed to the principles of inclusive and responsible tourism. These findings can be exploited by tourism practitioners, especially the governmental institutions, as a 
reference for adopting responsible tourism practices in any destination. Therefore, we are aware that the trademark effectiveness will depend on the communication strategy that will be adopted, and this needs to be tested in the medium term.

Finally, starting from the meaning of the word "inclusive" that refers to the concept of "social inclusion" as the opposite of the exclusion, and that relies on the active acceptance of one person or group by another, a further development of this line of research will be represented by the diversity management approach.

Author Contributions: All authors contributed equally to this work. All authors have read and agreed to the published version of the manuscript.

Funding: This research was funded by the "E-Parks-Environmental and Administrative Knowledge Networks for a Better Tourist Attractiveness in Protected Natural Areas" research project-Interreg V-A Greece-Italy Programme, MIS CODE 5003237.

Conflicts of Interest: The authors declare no conflict of interest.

\section{References}

1. Dixon, J.A.; Sherman, P.B. Economic of protected areas. Ambio J. Hum. Envrion. 1991, 20, 68-74.

2. Sharpley, R. Tourism and sustainable development: Exploring the theoretical divide. J. Sustain. Tour. 2000, 8, 11-19. [CrossRef]

3. Neto, F. A New Approach to Sustainable Tourism Development: Moving Beyond Environmental Protection, DESA Discussion Paper No. 29. 2003. Available online: https:/ / www.un.org/esa/esa03dp29.pdf (accessed on 24 November 2020).

4. Europarc Federation. European Charter for Sustainable Tourism in Protected Areas. 2010. Available online: https://www.europarc.o $\mathrm{rg}$ /library / europarc-events-and-programmes/european-charter-for-sustainable-tourism/ (accessed on 20 November 2020).

5. Jarvis, N.; Weeden, C.; Simcock, N. The Benefits and Challenges of Sustainable Tourism Certification: A Case Study of the Green Tourism Business Scheme in the West of England. J. Hosp. Tour. Manag. 2010, 17, 83-93. [CrossRef]

6. Manzoor, F.; Wei, L.; Asif, M.; ul Haq, M.Z.; ur Rehman, H. The Contribution of Sustainable Tourism to EconomicGrowth and Employment in Pakistan. Int. J. Envrion. Res. Public Health 2019, 16, 3785. [CrossRef] [PubMed]

7. Liu, J.C.; Sheldon, P.J.; Var, T. Resident perception of the environmental impacts of tourism. Ann. Tour. Res. 1987, 14, 17-37. [CrossRef]

8. Fleming, W.R.; Toepper, L. Economic impact studies: Relating the positive and negative impacts to tourism development. J. Travel Res. 1990, 29, 35-42. [CrossRef]

9. Puczko, L.; Ratz, T. Tourist and resident perceptions of the physical impacts of tourism at Lake Balaton, Hungary: Issues for sustainable tourism management. J. Sustain. Tour. 2000, 8, 458-478. [CrossRef]

10. Archer, B.; Cooper, C.; Ruhanen, L. The positive and negative impacts of tourism. Glob. Tour. 2005, 3, 79-102.

11. Blackstock, K.L.; White, V.; McCrum, G.; Scott, A.; Hunter, C. Measuring Responsibility: An Appraisal of a Scottish National Park's Sustainable Tourism Indicators. J. Sustain. Tour. 2008, 16, 276-297. [CrossRef]

12. UNEP; UNWTO. Making Tourism More Sustainable-A Guide for Policy Makers. 2005, pp. 11-12. Available online: https: //wedocs.unep.org/handle/20.500.11822/8741?show=full (accessed on 26 November 2020).

13. O'Halloran, R.M. Concessions in National Parks: Responsible Tourism. Hosp. Rev. 1993, 11, 5.

14. Bramwell, B.; Lane, B.; McCabe, S.; Mosedale, J.; Scarles, C. Research Perspectives on Responsible Tourism. J. Responsible Tour. 2008, 16, 253-257. [CrossRef]

15. Frey, N.; George, R. Responsible tourism management: The missing link between business owners' attitudes and behaviour in the Cape Town tourism industry. Tour. Manag. 2010, 31, 621-628. [CrossRef]

16. Goodwin, H. Chapter 1 What is Responsible Tourism; Goodwin, H., Ed.; Goodfellow Publishers: Oxford, UK, 2016. [CrossRef]

17. Setola, N.; Marzi, L.; Torricelli, M.C. Accessibility indicator for a trails network in a Nature Park as part of the environmental assessment framework. Environ. Impact Assess. Rev. 2018, 69, 1-15. [CrossRef]

18. United Nation. Accessibility and Development-Mainstreaming Disability in the Post-2015 Development Agenda. 2015. Available online: https:/ / www.un.org/disabilities/documents/accessibility_and_development.pdf (accessed on 21 October 2020).

19. United Nations. Environmental Accessibility and Its Implications for Inclusive, Sustainable and Equitable Development for All; Rapley, C.E., Ed.; United Nations: New York, NY, USA, 2013. Available online: https:/ /www.un.org/disabilities/documents/accessibilit Y_and_development_june2013.pdf (accessed on 25 October 2020).

20. Berno, T.; Bricker, K. Sustainable Tourism Development: The Long Road from Theory to Practice. Int. J. Econ. Dev. 2001, 3, 1-28.

21. Benedetto, G.; Carboni, D.; Corinto, G.L. Governance of Sustainable Tourism in a Vast Area Surrounding a National Park. Procedia Environ. Sci. 2016, 32, 38-48. [CrossRef]

22. Miller, G.; Twining-Ward, L. Monitoring for a Sustainable Tourism Transition: The Challenge of Developing and Using Indicators, 1st ed.; CABI: Wallingford, UK, 2005.

23. Fennell, D. Tourism Ethics; Channel View Publications: Clevedon, UK, 2006. 
24. Kim, M.J.; Park, J.Y.; Lee, C.K.; Chung, J.Y. The role of perceived ethics in the decision-making process for responsible tourism using an extended model of goal-directed behavior. Int. J. Tour. Hosp. Res. 2017, 31, 5-25. [CrossRef]

25. Goodwin, H. What is Responsible Tourism? 2014. Available online: http://responsibletourismpartnership.org/what-is-responsi ble-tourism (accessed on 18 November 2020).

26. Bianchi, P.; Cappelletti, G.M.; Mafrolla, E.; Sica, E.; Sisto, R. Accessible Tourism in Natural Park Areas: A Social Network Analysis to Discard Barriers and Provide Information for People with Disabilities. Sustainability 2020, 12, 9915. [CrossRef]

27. Goodwin, H.; Font, X. Progress in Responsible Tourism; Goodfellow: Oxford, UK, 2012; Volume 2, pp. 1-122.

28. Burrai, E.; Buda, D.M.; Stanford, D. Rethinking the ideology of responsible tourism. J. Sustain. Tour. 2019, 27, 992-1007. [CrossRef]

29. Cape Town Declaration. Cape Town Conference on Responsible Tourism in Destinations. 2002. Available online: https: / / responsibletourismpartnership.org/cape-town-declaration-on-responsible-tourism/ (accessed on 24 October 2020).

30. Chan, J.K.L.; Xin, T. Exploring Definitions and Practices of Responsible Tourism in Kinabalu National Park, Sabah, Malaysia. J. Tour. Hosp. Manag. 2015, 3, 87-101. [CrossRef]

31. Wheeller, B. Tourism's troubled times: Responsible tourism is not the answer. Tour. Manag. 1991, 12, 91-96. [CrossRef]

32. Krantz, D.; Chong, G. The Market for Responsible Tourism Products: With a Special Focus on Latin America and Nepal. 2009. Available online: https:/ / www.responsibletravel.org/ (accessed on 23 October 2020).

33. Mihalic, T. Sustainable-responsible tourism discourse e Towards 'responsustable' Tourism. J. Clean. Prod. 2016, 111, 461-470. [CrossRef]

34. United Nations. Disability and Development Report: Realizing the Sustainable Development Goals by, for and with Persons with Disabilities. 2018. Available online: https://www.un.org/development/desa/disabilities/publication-disability-sdgs.html (accessed on 26 November 2020).

35. Fennell, D.A. Responsible Tourism: A Kierkegaardian Interpretation. Tour. Recreat. Res. 2008, 33, 3-12. [CrossRef]

36. Wheeller, B. Sustaining the ego. J. Sustain. Tour. 1993, 1, 121-129. [CrossRef]

37. Caruana, R.; Glozer, S.; Crane, A.; McCabe, S. Tourists' accounts of responsible tourism. Ann. Tour. Res. 2014, 46, 115-129. [CrossRef]

38. Pappalardo, G.; Sisto, R.; Pecorino, B. Is the partnership governance able to promote endogenous rural development? A preliminary assessment under the Adaptive Co-management approach. Eur. Countrys. 2018, 10, 543-565. [CrossRef]

39. Prosperi, M.; Sisto, R.; Lopolito, A.; Materia, V.C. Local entrepreneurs' involvement in strategy building for waste valorisation within an agro-food technological district: A SWOT-SOR approach. Sustainability 2020, 12, 4523. [CrossRef]

40. Darcy, S. Setting a Research Agenda for Accessible Tourism. In STCRC Technical Report Seriespp. 48; Cooper, C., LacY, T.D., Jago, L., Eds.; Sustainable Tourism CRC: Queensland, Australian, 2006; Available online: http:/ /www.crctourism.com.au/BookShop/Boo kDetail.aspx?d=473 (accessed on 27 November 2020).

41. Darcy, S.; Dickson, T. A Whole-of-Life Approach to Tourism: The Case for Accessible Tourism Experiences. J. Hosp. Tour. Manag. 2009, 16, 32-44. [CrossRef]

42. United Nations. Takayama Declaration, on the Development of Communities-for-All in Asia and the Pacific. 2009. Available online: https:/ / www.accessibletourism.org/resources/takayama_declaration_top-e-fin_171209.pdf (accessed on 26 November 2020).

43. UNWTO. World Tourism Day 2016 "Tourism for All-promoting universal accessibility" Good Practices in the Accessible Tourism Supply Chain; UNWTO: Madrid, Spain, 2016.

44. Maller, C.; Townsend, M.; Pryor, A.; Brown, P.; St Leger, P. Healthy nature healthy people: 'contact with nature' a san upstream health promotion intervention for populations. Health Promot. Int. 2006, 21, 45-54. [CrossRef]

45. Tecău, A.S.; Brătucu, G.; Tescasiu, B.; Chitu, I.B.; Constantin, C.P.; Foris, D. Responsible Tourism-Integrating Families with Disabled Children in Tourist Destinations. Sustainability 2019, 11, 4420. [CrossRef]

46. Various Authors. Dichiarazione di Norcia. 2003. Available online: http://www.sibillini.net/primoPiano/eventi/convegnoDisabi li/DichiarazioneDiNorcia.htm (accessed on 5 December 2020).

47. Bianchi, P.; Cappelletti, G.M.; Sica, E.; Sisto, R. Stakeholder Involvement to Improve Accessibility in a Protect Natural Area: A Case Study. In Le Scienze Merceologiche Nell'era 4.0, Proceedings of the Atti del XXIX Congresso Nazionale di Scienze Merceologiche 2020, Salerno, Italy, 13-14 February 2020; Esposito, B., Malandrino, O., Sessa, M.R., Sica, D., Eds.; Franco Angeli: Milano, Italy, 2020; ISBN 978-88-351-0527-5.

48. Sisto, R.; Bianchi, P.; Cappelletti, G.M.; Sica, E. Granting tourism accessibility to disabled people in natural areas: A participatory approach. In Abstract Proceeding Book of 4th Singapore International Conference on Management, Business, Economic, and Social Science (4th SIMBES); Yayasan Sinergi Riset dan Edukas: Bandung, Indonesia, 2019; pp. 5-6. ISBN 978-602-5902-41-3.

49. Gillovic, B.; McIntosh, A. Accessibility and Inclusive Tourism Development: Current State and Future Agenda. Sustainability 2020, 12, 9722. [CrossRef]

50. Szczęsna, J.; Wojtanowicz, P. The Role of National Parks in Promoting Sustainable and Responsible Tourism. Barom. Reg. 2014, 12, 19-25.

51. Pugliapromozione-Agenzia Regionale del Turismo. Osservatorio Regionale. 2019. Available online: https://www.agenziapugli apromozione.it/portal/osservatorio-del-turismo (accessed on 7 November 2020). 